\title{
Beyond gender role stereotypes - the changing view of women in IT managerial positions
}

\author{
Celina Sołek-Borowska \\ Warsaw School of Economics
}

\section{Introduction}

Information Technology is rapidly changing the world; it has significantly changed the way we do things, and the way we communicate with people all over the world. IT has also advanced the teaching system used at all levels of education. The gradual transformation of the IT industry has entered all spheres of life.

However, inequality between women and men has persisted in terms of hiring and retention of women at all levels of information technology (IT). This accounts for the low number of girls who have had an understanding of computer modules in schools, to the low percentage of women/females who take up any IT course at an undergraduate level and more visibly the lack of females in excellent organisational and academic positions. Moreover, the belief exists that women are naturally equipped for less intense IT professions. It now has seemingly become a man's world due to the low participation of women in this sector. The situation is no different in the engineering sector.

Gender indifferences in IT careers seem to be affecting the competitiveness of countries and companies globally. The presence of women in IT jobs is quite low. Adding to that, in Poland only 13\% of IT students are women. In technological corporations there are fewer of them. The lack of IT specialists in Poland is assessed at 50,000 jobs and in Europe a shortage of 1 million is predicted by $2020^{1}$.

The attraction of skilled and competent women to traditionally male-dominated occupations, and their retention, have now become a great concern for today's organizations. Not enough is known about the challenges faced by women professionals

1 Forum Akademickie, Rusza największy program wspierający kobiety w informatyce "IT for SHE", https://forumakademickie.pl/news/rusza-najwiekszy-program-wspierajacy-kobiety -w-informatyce-it-for-she/ (accessed: 10.12.2019). 
who possess the credentials, skills and knowledge that would allow them to be considered, alongside their male counterparts for top-ranking positions. While, statistically, figures show an increase in women's representation in the Science, Engineering and Technology domain, academic research is yet to explore in greater depth both the reasons for women's continuing challenges they face at senior levels and their work experiences. The experiences of women in gender-atypical work contexts (e.g. information technology (IT) firms) continue to garner scholarly attention, given the rise in women entering non-traditional work domains ${ }^{2}$ and the many challenges faced by them in such contexts 3 . The main objective of the following paper is to identify the barriers for women in IT managerial positions. This paper intends to fill this research gap considering the context of the Polish market and women in IT managerial roles.

\section{IT industry as highly gendered}

The IT industry is mainly categorized as a knowledge intensive industry. Although at first glance the IT profession appears "gender neutral"4, where men and women play equal and impartial roles, irrespective of gender, and work expectations are set without regard to gender 5 , the profession is nonetheless "gendered"6. Bhattacharjee and Takruri-Rizk state that the IT culture is characterized by competitiveness and individualism, and is sexualized and gendered, with women employed in such organizations often having to adjust and fit into the male-dominated work culture ${ }^{7}$. Gender imbalance is still a key issue in the industry ${ }^{8}$. Internet pioneer Martha Lane Fox identified the under-representation of women in technology companies

2 J.E. Wallace, Gender and supportive co-worker relations in the medical profession, "Gender, Work \& Organization" 2014, vol. 21, no. 1, pp. 1-17.

3 O. Kyriakidou, Fitting into technical organizations? Exploring the role of gender in construction and engineering management in Greece, "Construction Management and Economics" 2012, vol. 30, no. 10, pp. 845-856.

4 L. Miller et al., Saying welcome is not enough: women, information system and equity in work, "Career Development" 2000, vol. 5, no. 7, pp. 379-389.

5 S. Jayaweera, T. Sanmugam, L. Wanasundara, Information and communication technologies and gender in Sri Lanka, Institute of Social Studies Trust, New Delhi 2006; G.P. Sudhakar, A. Farooq, S. Patnaik, Soft factors affecting the performance of software development teams, "Team Performance Management" 2011, vol. 17, no. 3, pp. 187-205.

6 D.M.W. Kovacs, M. Ryan, A. Haslam, The glass-cliff: women's career paths in the UK private IT sector, "Equal Opportunities International" 2006, vol. 25, no. 8, pp. 674-687.

7 S.D Bhattacharjee, H. Takruri-Rizk, Gender segregation and ICT: an Indo-British comparison, "International Journal of E-Politics" 2011, vol. 2, no. 1, pp. 45-67.

8 A.M. Balcita, D. Carver, M.L. Soffa, Shortchanging the future of information technology: the untapped resource, "SIGCSE Bulletin" 2002, vol. 34, no. 2, pp. 32-35; G. Valenduc, P. Vendramin, Work organisation and skills in ICT professions: the gender dimension, [in:] Proceedings of ICT, the Knowledge Society and Changes in Work, Den Haag 2005. 
as a great concern during her recent Richard Dimbleby public lecture broadcast on the $\mathrm{BBC}^{9}$. The social constructionist perspective also shows the social construction of IT as a male domain that is interpreted as incompatible with the social construction of women's identity ${ }^{10}$. Not surprisingly, STEM industries face the common issue of attracting and retaining women as an untapped resource ${ }^{11}$.

Poland ranks high, fifth among European countries, in terms of the number of registered enterprises from the ICT sector, which is presented in Table 1.

Table 1. Number of registered companies from ICT sector

\begin{tabular}{|l|c|r|r|r|r|r|r|}
\hline \multicolumn{1}{|c|}{ Country/year } & \multicolumn{1}{c|}{2008} & \multicolumn{1}{c|}{2009} & \multicolumn{1}{c|}{2010} & \multicolumn{1}{c|}{2011} & \multicolumn{1}{c|}{2012} & \multicolumn{1}{c|}{2013} & \multicolumn{1}{c|}{2014} \\
\hline Great Britain & 132,943 & - & 128,957 & \multicolumn{1}{c|}{-} & - & - & 163,325 \\
\hline France & - & 69,900 & 95,204 & 94,627 & 108,515 & 126,705 & 131,835 \\
\hline Italy & 108,507 & 105,331 & 104,614 & 103,239 & 103,075 & 101,893 & 102,330 \\
\hline Germany & 70,134 & 71,252 & 74,973 & 80,767 & 82,554 & 86,378 & 97,972 \\
\hline Poland & 42,833 & 48,517 & 52,566 & 57,887 & 63,462 & 69,169 & 76,302 \\
\hline Holland & 30,898 & 33,998 & 47,953 & 51,135 & 55,825 & 70,914 & 73,131 \\
\hline Spain & - & - & 44,222 & 45,095 & 48,986 & 49,863 & 52,204 \\
\hline Sweden & 39,215 & 40,041 & 41,876 & 43,925 & 44,186 & 43,903 & 44,913 \\
\hline Romania & 19,519 & 19,190 & 17,157 & 16,127 & 17,318 & 18,188 & 19,485 \\
\hline Austria & 13,617 & 13,466 & 14,420 & 14,798 & 15,088 & 15,388 & 15,795 \\
\hline Slovakia & 2,906 & 1,512 & 9,847 & 11,719 & 11,838 & 13,022 & 14,324 \\
\hline Denmark & 10,624 & 10,797 & 11,650 & 12,396 & 12,733 & 13,074 & 13,619 \\
\hline Portugal & 12,408 & 12,052 & 11,747 & 12,004 & 12,035 & 12,680 & 12,975 \\
\hline Norway & 12,113 & 11,345 & 11,237 & 11,215 & 11,546 & 11,817 & 11,939 \\
\hline Greece & - & - & - & 9,054 & 8,939 & 8,975 & 9,455 \\
\hline Bulgaria & 5,752 & 7,126 & 7,279 & 7,685 & 8,228 & 9,024 & 9,452 \\
\hline Finland & 7,402 & 7,344 & 7,517 & 7,679 & 7,825 & 8,130 & 8,185 \\
\hline Slowenia & 4,162 & 4,703 & 5,170 & 5,422 & 5,676 & 6,091 & 6,614 \\
\hline Croatia & 4,432 & 4,879 & 5,111 & 5,134 & 5,187 & 5,438 & 5,630 \\
\hline Łatvia & 2,559 & 2,780 & 3,151 & 3,406 & 4,391 & 5,063 & 5,432 \\
\hline Lithuania & 2,415 & 2,270 & 2,532 & 2,779 & 3,435 & 3,818 & 5,127 \\
\hline Estonia & 1,849 & 1,394 & 2,266 & 2,731 & 2,917 & 3,364 & 3,527 \\
\hline Luxemburg & 1,554 & 1,618 & 1,694 & 1,755 & 1,838 & 1,960 & 2,054 \\
\hline Macedonia & - & - & - & 947 & 1,065 & 1,143 & 1,170 \\
\hline
\end{tabular}

Source: Perspektywy rozwoju polskiej branży ICT do roku 2025, https://www.parp.gov.pl/component /publications/publication/perspektywy-rozwoju-branzy-ict-do-roku-2025 (accessed: 2.01.2020).

$9 \quad$ M.L. Fox, Dot everyone - power, the internet and you, Richard Dimbleby Lecture, 2015, March 30, www.bbc.co.uk/mediacentre/speeches/2015/martha-lane-fox-dot-everyone (accessed: 10.11.2019).

10 M.A. Lemons, M. Parzinger, Gender schemas: a cognitive explanation of discrimination of women in technology, "The Journal of Business and Psychology" 2007, vol. 22, no. 1, pp. 91-98.

11 J.L. Glass et al., What's so special about STEM? A comparison of women's retention in STEM and professional occupations, "Social Forces" 2013, vol. 92, no. 2, pp. 723-756. 
The above data show the great potential of this sector, both for economic growth and directly for employment. The large number of enterprises is a potential on the basis of which further international successes of Polish entrepreneurs can be built. Polish companies constitute around $7.6 \%$ of the total number of enterprises operating in the sector in the European Union. This emphasizes the importance of Polish companies both on a national scale and from a European perspective. The dynamics of the number of enterprises also allows for the forecast that Poland's position on the international arena will strengthen. The average annual growth of the studied variable over the years 2009-2014 was over 10.1\% (CAGR ${ }^{12}$ ). This gives Poland the seventh place in terms of average growth dynamics among all the analyzed European countries. It is worth noting, however, that among the 10 countries with the largest number of enterprises, Poland came in third. The growing number of enterprises from the ICT sector is also in line with increasing the industry's potential to generate innovative solutions of international importance.

\section{Gender stereotyping - literature review}

Stereotypes are "beliefs about the characteristics, attributes, and behaviors of members of certain groups"13. Gender stereotyping of the managerial role occurs when the characteristics believed to be necessary to fulfil the role are ascribed to one sex ${ }^{14}$. Attributes such as achievement orientation, forcefulness and strength in decision-making are commonly ascribed to men, and these traits are considered to be essential to fulfil jobs gender-typed as male, such as management and leadership roles ${ }^{15}$.

Research spanning three decades has shown that management is strongly associated with a male gender type, with male managers and male management students in particular believing that males are more likely to have the necessary characteristics, attitudes and temperament to achieve managerial success.

12 Perspektywy rozwoju polskiej branży ICT do roku 2025, https://www.parp.gov.pl/compo nent/publications/publication/perspektywy-rozwoju-branzy-ict-do-roku-2025 (accessed: 2.01.2020).

13 J.L. Hilton, W. von Hippel, Stereotypes, "Annual Review of Psychology" 1996, vol. 47, pp. 237-271.

14 V.E. Schein, A global look at psychological barriers to women's progress in management, "Journal of Social Issues" 2001, vol. 57, no. 4, pp. 675-688; V.E. Schein, Women in management: reflections and projections, presented at the 26th International Congress of Applied Psychology, Athens, 17 July 2006.

15 K. Lyness, M. Heilman, When fit is fundamental: performance evaluations and promotions of upper-level female and male managers, "Journal of Applied Psychology" 2006, vol. 91, no. 4, pp. $777-785$. 
The pervasive nature of this phenomenon is illustrated clearly in an early study by Brenner, Tomkiewicz, and Schein ${ }^{16}$, who reported that the attitudes of male middle managers in their sample were found to be similar to the attitudes held by male managers more than a decade prior ${ }^{17}$. A disturbing finding in this research was that the relationship between gender stereotypes and male attitudes toward the requisite management characteristics had actually strengthened.

Gender stereotyping has also been shown to have an impact on the evaluation of women's performance when they have achieved a management role. Eagly and Karau ${ }^{18}$ considered that there was a significant incongruity between the gender roles often attributed to women, and the roles considered to be appropriate for a leader.

Prejudicial attitudes toward women were the result of this incongruity, which often took the form of negative assessment of women to fill leadership roles ${ }^{19}$. Recent findings have clearly illustrated that there continues to be a perception of a lack of fit between the requirements of line management roles and the stereotypical attributes ascribed to women, with women in these roles receiving lower performance ratings than either their female colleagues in staff jobs, or their male counterparts in either line or staff jobs ${ }^{20}$. This suggests that particular management roles, such as line management, are more strongly associated with the characteristics attributed to males, rather than females.

These are overt examples of how gender stereotyping perspectives can influence the career of female managers. There are also covert examples as suggested by a large Australian study into attitudes of opportunities within the financial industry workplace. It found that over a third of male respondents ( 37 per cent) believed that women were less committed to their careers "because they have babies and leave the company while their children are young" 21 . Only 19 per cent of female respondents agreed with this statement. Such attitudes toward women will

16 O. Brenner, J. Tomkiewicz, V.E. Schein, The relationship between sex role stereotypes and requisite management characteristics revisited, "Academy of Management Journal" 1989, vol. 32, no. 3, pp. 662-669.

17 V.E. Schein, The relationship between sex roles stereotypes and requisite management characteristics, "Journal of Applied Psychology" 1973, vol. 57, no. 2, pp. 95-100; V.E. Schein, Relationship between sex role stereotypes and requisite management characteristics among female managers, "Journal of Applied Psychology" 1975, vol. 60, no. 3, pp. 340-344.

18 A.H. Eagly, S.J. Karau, Role congruity theory of prejudice toward female leaders, "Psychological Review" 2002, vol. 109, pp. 573-598.

19 Ibidem.

20 K. Lyness, M. Heilman, When fit is fundamental...

21 L.V. Still, Glass ceilings and stick floors: barriers to the careers of women in the Australian finance industry, Human Rights and Equal Opportunity Commission, Commonwealth of Australia, Canberra 1997. 
be likely to underpin decisions relating to selection, professional development and promotion possibilities. However, these findings illustrate a commonly held view, which does not necessarily reflect the reality of the majority of women in contemporary management positions.

\section{Gender stereotypical attitudes}

There is now a growing recognition that a relatively large proportion of women in management roles are remaining childless, or even "partnerless" 22 in order to continue on in their senior or executive management career. One study in the USA has reported that almost half (49 per cent) of women classified as high achievers were childless. This was in stark contrast to male colleagues, where only 19 per cent were childless ${ }^{23}$. The above results outline how gender stereotyping can influence the career advancement of women in management. There is evidence that negative stereotyping by others is a powerful barrier to the career advancement of women in management. Such attitudes are pervasive and deeply entrenched and continue to exert an impact on women's career advancement in managerial roles.

It would appear that the stereotypes and preconceptions of women's roles and abilities, rather than the actual abilities and qualities women possess have been instrumental in creating barriers to women's career advancement. Underpinning such stereotypical views are attitudes and beliefs that management is a male domain.

This theory was clearly elucidated in the seminal book Women Managers: Travellers in a Male World ${ }^{24}$, and similar restraints are reported in research almost two decades later ${ }^{25}$.

It is worth remembering that such views have the capacity to impact the career advancement of women in management roles from recruitment and selection practices, training opportunities, allocation of roles, overseas placements, through to decisions related to promotion opportunities.

This paper proposes that gender stereotypical views may also affect perceptions about future representation of women in senior leadership roles, if men, rather than women, continue to be seen as a more appropriate person-job fit in senior

22 G.J. Wood, J.N. Newton, Childlessness - a choice among women in Management?, "Gender, Work and Organization" 2006, vol. 3, no. 4, pp. 338-358; G.J. Wood, J.N. Newton, Facing the wall' - 'equal'opportunity for women in management?, "Equal Opportunities International" 2006, vol. 25, no. 1, pp. 8-24.

23 S. Hewlett, Baby Hunger: The New Battle for Motherhood, Atlantic Books, London 2002.

24 J. Liu, D. Wilson, The unchanging perception of women as managers, "Women in Management Review" 2001, vol. 16, no. 4, pp. 163-173.

25 J. Marshall, Women Managers: Travellers in a Male World, John Wiley \& Sons, Chichester 1984. 
management roles. It is argued that given the pervasive nature of gender stereotyping in attitudes toward the role of management that predictions are the longer term possibility of women filling senior management roles in equal proportion to their male colleagues, will still be influenced by a "think manager-think male" perspective.

Although it has been reported that male managers' attitudes toward women in management have remained stable over previous decades, there has been a change in the attitudes of women toward women in management roles as evidenced by a reduced tendency to gender type the managerial position 26 and a propensity to consider that women and men are both capable of possessing characteristics that are appropriate to the management role.

Along with the increase in the number of women entering management at junior and middle management level, there is a heightened level of awareness that exists over the last decade toward a more politically correct environment, particularly in relation to employment, gender issues and legal repercussions arising from inappropriate organisational behaviour. For example, it is now not unusual for women to bring gender discrimination charges against employers - and win. Successful outcomes have resulted in millions of dollar payouts in settlement costs ${ }^{27}$. This suggests that female managers may have a more confident outlook regarding the suitability of women in management roles.

\section{Job embeddedness}

This study draws upon JE (job embeddedness) ${ }^{28}$ as a theoretical frame to explain the specific strategies used by women on IT managerial to embed and stay in their jobs. Mitchell et al. state that "people stay if they are satisfied with their jobs and committed to their organizations and leave if they aren't" 29 . There are women who stay in gender-atypical contexts, facing the dilemma of adverse gender expectations at work, even though it comes at a social and personal cost of being part

26 K.A. Dodge, F.D. Gilroy, L.M. Fenzel, Requisite management characteristics revisited: two decades later', [in:] N. Struthers (ed.), Gender in the Workplace, "Journal of Social Behavior and Personality" 1995, vol. 10, special issue, pp. 253-264.

27 E. Porter, UBS ordered to pay \$29 million in sex bias lawsuit, "The New York Times" 2005, 7 April.

28 E. Zhao, L. Liu, Comments on development of job embeddedness about study on turnover and exploration into application in enterprises, "Asian Social Science" 2010, vol. 7, no. 6 , pp. 63-70.

29 T. Mitchell et al., Why people stay: using job embeddedness to predict voluntary turnover, "Academy of Management Journal" 2001, vol. 44, no. 6, pp. 1102. 
of a technical/engineering diaspora. For example, Gherardi and Poggio ${ }^{30}$ show that women in male-dominant work employ the strategy of behaving "like a man" to get ahead in their jobs. These strategies are not mere random behaviors but consciously developed by women to suit the demands of their work. In their pioneering work, Mitchell et al. ${ }^{31}$ defined JE as encompassing a broad collection of influences on employee retention. Although this theory is relatively young in the management discipline ${ }^{32}$, it has contributed significantly to understanding human mobility at work. The theory discusses the dimensions of link, fit and sacrifice existing within an individual's organization and community that can be likened to a web that works toward enmeshing the individual to stay in the organization ${ }^{33}$.

\section{Research methodology}

\section{Research problem and questions}

The main purpose of this paper is to fill the research gap on indicating what are the barriers for women in IT managerial positions. To meet the purpose of the paper and to answer main research question the study focuses on addressing the following specific research questions have been asked:

RQ1: What career strategies did women use to get to the top?

RQ2: What barriers did women have to overcome to be able to pursue their career in IT?

RQ3: What stereotypes did women face when moving up for a managerial position?

This research followed the recommendations of Dubé and Paré ${ }^{44}$ regarding the protocol development and expert validation of the interviews. Three IT professors validated the instrument in the period of January to February 2019. Following minor revisions to the wording of the questions, the main study was carried out between April and May 2019.

30 S. Gherardi, B. Poggio, Creating and recreating gender order in organizations, "Gender \& Society" 2001, vol. 4, no. 2, pp. 139-158.

31 T. Mitchell et al., Why people stay...

32 D.C. Feldman, T.W.H. Ng, Careers: mobility, embeddedness, and success, "Journal of Management" 2007, vol. 33, no. 3, pp. 350-377.

33 M. Zhang, D.D. Fried, R.W. Griffeth, A review of job embeddedness: conceptual, measurement issues, and directions for future research, "Human Resource Management Review" 2012, vol. 22, no. 3, pp. 220-231.

34 L. Dube, G. Pare, Rigor in information systems positivist case research: current practices, trends and recommendations, "MIS Quarterly" 2003, vol. 27, no. 4, pp. 597-635. 
The following research is based on 10 semi-structured interviews with women who occupy IT managerial positions. Participants were self-recruited following a call for participation in research posted to graduate students at Warsaw School of Economics.

The research project aimed to assess success factors associated with women pursuing careers in IT managerial positions. Women were asked to reflect the influence of their education on their career, the importance of mentorship, motives to choose a career in IT, strategies that helped to get to their current position and barriers that they had to overcome particularly to pursue their career.

The following research discusses mainly barriers for women in their career advancement. The production of data followed GDPR guidelines. The overall methodological approach was based on an understanding of fieldwork as an interactional accomplishment, and a view of research as a collaborative partnership between the researcher and the researched. The interviews were run for two months and each interview lasted around 30 minutes.

Table 1. Profile of the interviewee

\begin{tabular}{|c|l|l|c|l|l|}
\hline Interviewee & \multicolumn{1}{|c|}{$\begin{array}{c}\text { Education } \\
\text { background }\end{array}$} & Employment sector & Age & $\begin{array}{c}\text { Marital } \\
\text { status }\end{array}$ & $\begin{array}{l}\text { Years in the } \\
\text { IT business }\end{array}$ \\
\hline A1 & $\begin{array}{c}\text { Bachelor degree } \\
- \text { Technological }\end{array}$ & $\begin{array}{l}\text { Construction } \\
\text { company }\end{array}$ & $41-45$ & Single & $\begin{array}{l}\text { Above } 16 \\
\text { years }\end{array}$ \\
\hline A2 & Management degree & $\begin{array}{l}\text { IT } \\
\text { telecommunication }\end{array}$ & $36-40$ & Single & From 11-15 \\
\hline A3 & Economics & Banking & $36-40$ & Married & From 11-15 \\
\hline A4 & $\begin{array}{l}\text { Linguistics, } \\
\text { Management }\end{array}$ & Banking & $36-40$ & Single & From 11-15 \\
\hline A5 & Banking and Finance & Banking & $36-40$ & Married & From 11-15 \\
\hline A6 & Management & Banking & Below 30 & Marrried & $\begin{array}{l}\text { Up to five } \\
\text { years }\end{array}$ \\
\hline A7 & IT & Banking & $30-35$ & Single & From 11-15 \\
\hline A8 & Economics & Banking & $36-40$ & $\begin{array}{l}\text { Married } \\
\text { with 2 } \\
\text { kids }\end{array}$ & From 11-15 \\
\hline A9 & Management & Banking & $30-35$ & Single & From 11-15 \\
\hline A10 & Finance and Banking & Telecommunication & $30-35$ & Single & From 6-10 \\
\hline
\end{tabular}

Source: own development.

The data were analyzed using content analysis, as recommended by Bardin ${ }^{35}$. What emerged is that $80 \%$ of interviewee had no IT background, $60 \%$ of them were single.

35 L. Bardin, Content analysis, Edições, São Paulo 2011. 


\section{Research results}

\section{Career strategies}

As is evident in the literature, the IT culture globally is competitive, individualised, sex segregated, gendered and often offering a chilly climate for women in terms of organisational culture. IT workplaces are not always ideal for women's progression and well-being in the sense that women often have to "adjust" and fit into a male-dominated work culture ${ }^{36}$.

Lemons and Parzinger state that women who stay in IT professions have the strongest non-traditional gender schemas compared to women from the general public, especially in IT project work, where men outnumber women ${ }^{37}$.

Successful performance by women, particularly in masculine and demanding situations, is perceived as a freak phenomenon due not to their real abilities but to other external factors ${ }^{38}$. Similarly, Rigg and Sparrow ${ }^{39}$ indicated that women are caught between two forms of male prejudice. When women behave with more feminine qualities, men like them but perceive them as unintelligent and incompetent. At the same time, when women behave and perform assertively men see them as intelligent and competent, but they are disliked for being unfeminine $e^{40}$.

To answer the first research question, women were asked what were their career strategies they used to get to the top.

A1 respondent said: "I had no strategy to reach that position. The bosses recommended me for the right positions with the right person. Successive positions in the company directed me to the position in which I am now". A2 respondent adds: "Opportunities appeared, I took them but it was connected with hard work and determination in achieving my goals". The answer is in line with A7 respondent

36 M. Griffiths, K. Moore, H. Richardson, Celebrating heterogeneity? A survey of female ICT professionals in England, "Information, Communication and Society" 2007, vol. 10, no. 3, pp. 338-357; N. Gupta, Rethinking the relationship between gender and technology: a study of the Indian example, "Work Employment and Society", December 2015, vol. 29, no. 4, pp. 661-672.

37 M.A. Lemons, M. Parzinger, Gender schemas....

38 R.M. O'Neill, Gender and race in mentoring relationships: a review of the literature, [in:] D. Clutterbuck, B.R. Ragins (eds), Mentoring and Diversity: An International Perspective, Butterworth-Heinemann, Oxford 2002, pp. 1-22.

39 C. Rigg, J. Sparrow, Gender, diversity and working styles, "Women in Management Review" 1994, vol. 9, no. 1, pp. 9-16.

40 Ibidem. 
who says: "I have always had clear objectives, which I want to achieve. Consequence of actions and diligence of executed work brought me to the current position". A10 echoes: "chance, hard work and good opportunities".

The respondents' narratives revealed that task orientation, hard work, taking challenges and risks at work were the major work expectations of the IT industry. These expectations are compatible with masculine traits, as characterized by the masculine terms of authoritative, tough, individualistic ${ }^{41}$, aggressive, persistence, competitive, assertive ${ }^{42}$, masculine, task orientation ${ }^{43}$.

Even though the women do not want to admit directly they had a strategy, it is said between the lines. Like A8: "I didn't have a strategy. I do what I like, I set objectives, but what I was able to achieve was hard work. I always repeat to myself that successful people do what other do not want to do". A3 said: "I always wanted to learn, develop. I was applying for positions inside the company for which I did not have the qualifications. But my bosses allowed me to learn, they believed in me that I will manage". A5 adds: "I was promoted because of the job well done, but when I saw I am not learning anything new I was either changing to a different position or applying for a new one". A7: "I was staying in the company up to the moment where I felt I learn, I develop. When I felt it has stopped I was changing a company".

It can be stated that gendered work role expectations, emanating from masculine norms and ideologies in IT firms, compel women to intentionally engage in gendered strategies if they are to stay and be promoted in their positions. Some women adopted masculine characteristics. The respondents did this in various ways, by being task oriented and undertaking more challenges at work.

To sum up the preceding discussion, findings from the study show three different gendered strategies used by women not only to survive but to be promoted in gender-atypical work environments. In the first strategy, some women adopted masculine characteristics. In the second, women used a hybrid approach by being conscious of required gender roles in different situations. The third was demonstrating self-confidence, where women worked hard and showed extraordinary performance in order to develop their self-confidence.

41 M. Syed, P. Murray, A cultural feminist approach towards managing diversity in top management teams, "Equal Opportunities International” 2008, vol. 27, no. 5, pp. 413-432.

42 L. Karakowsky, K. McBey, Y. Chuang, Perception of team performance: the impact of group composition and task based cues, "Journal of Managerial Psychology" 2004, vol. 19, no. 5, pp. 506-525.

43 C. Erwin, Social identity in diverse workgroups: an empirical investigation, "Research Journal of International Studies" 2010, vol. 15, pp. 69-76. 


\section{Gender stereotypes}

To answer the second and third research questions, women were asked what barriers they had to overcome in getting their position. In general, research on gender stereotypes reveals that people consider women to have more communal qualities (e.g. are more gentle, kind, supportive, expressive, affectionate, and tactful) and men more agentic qualities (e.g. are more assertive, competitive, daring, and courageous) ${ }^{44}$. Despite the considerable increase in the proportion of women managers over this period of time and the emergent call for a greater emphasis on feminine characteristics in management, men and women of varying age, education, and work experience still described a good manager as possessing predominantly masculine characteristics.

What is quite interesting, women do not refer directly to stereotypes but instead say for example A1: "Being a woman means that you have to work/prove more than men to be considered a competent person".

We can say that the attitude is changing as A3 respondent says: "I didn't have to overcome any barriers, I was meeting bosses who believed in women, even though they were men themselves". A9 respondent expresses the same view, saying: "No barriers, I had very good bosses, who trusted me, gave a freedom in executing tasks. They were available when I needed them. They were open for new ideas". A4 and A10 also talk about none barriers. Only four respondents directly talk about stereotypes: A5 mentions: "When women talk men seem do not really listening to it" and A6: "Role of women in IT is no regarded seriously. Knowledge has to be proven all the time. As an IT project manager you have to prove your knowledge, customers will go to the IT analyst or IT architect (assuming both are men) to confirm that a woman IT manager is right".

A7 respondent is in line with A6 respondent: "In my opinion a woman has to prove her competences all the time, unless she does not prove it she is not regarded as competent amongst men colleague or clients. I had to work a lot to gain respect". A8 respondent adds: "men do not want women in my company, especially on such positions". A4 respondent adds that "a strategy that worked out in her case is when a woman can move away the elements of her femininity and change it for professionalism, adjust style of behaviour to being in a corporate environment".

Why have managerial stereotypes persisted in placing primary emphasis on masculine characteristics? Powerful forces serve to perpetuate existing stereotypes, whatever group of people is being stereotyped and whatever the content

44 J.E. Williams, D.L. Best, Measuring sex stereotypes: A multination study, Sage, Newbury Park 1990. 
of its stereotype may be ${ }^{45}$. In the case of managerial stereotypes, men and women who chose a career path may not seek to be managers if they do not see themselves as fitting the prevailing stereotype of managers. In addition, organizations may only select applicants for managerial positions whom they see as adhering to managerial stereotypes. Further, organizations tend to exert strong pressures on their members to conform to ways acceptable to other members, particularly those in power.

\section{Conclusions}

Being a minority group in the IT sector, professional women face challenges and barriers. Gender inclusivity in the sense of involving more women in the workforce is nowadays considered to be a wise business decision. Earlier, it was considered to be corporate social responsibility on part of the companies. This is no longer the case. According to the NASSCOM Report, the reason behind this change in attitude is due to the fact that women are actually contributing significantly in the development of a company. Women are a vital part of the workforce and their participation ensures continuous growth for the organization. Women bring in unique qualities like emotional intelligence and empathy in a decision-making process. There is direct correlation between employment of women and economic wellbeing of a nation 46 .

This research was designed to explore women's efforts not only to stay in gendered, and hence challenging, environments but also to be promoted in such a setting. Findings show that the IT industry is predominantly masculine and women are expected to perform roles similar to their male counterparts. The study identified different strategies used by women to compromise their gender identities and link and fit with their work environments. It is hoped that this study reveals the importance of protecting the pride of women engineers and the significance of retaining them. Survival and sustaining employment in gender-atypical work contexts is challenging for women irrespective of the industry they work in and the issues they experience. Hence, academics and practitioners can create a more positive experience for women in male-dominant work contexts by understanding the strategies women use to link and fit with the organizational environment.

45 D.L. Hamilton, J.W. Sherman, Stereotypes, [in:] R.S. Wye Jr., T.K. Srull (eds), Handbook of social cognition, vol. 2, applications, Erlbaum, Hillsdale 1994, pp. 1-68.

46 NASSCOM Report. Gender inclusivity and diversity in the Indian IT-BPO industry, NASSCOM, New Delhi 2008. 
Such understanding and better work environments in gender-atypical work contexts are important for women who like challenges and who want to enter and stay in male-dominant occupations.

Managers of IT firms need to create positive work environments for their women employees that aid them to fit and link with their workplaces.

The present study has a number of limitations. The sample size is small, and the study scope is narrow, with an individual focus. The views of male counterparts and management of these selected organizations were not sought. Future research can include the perspectives of all parties to obtain a broader and more comprehensive picture. Another limitation is that the cultural dimensions of these organizations were not considered.

\section{Acknowledgments}

The author wish to acknowledge that this paper was made possible through the support and guidance provided by the Statutory Research executed within the project: $\mathrm{KZiF} / \mathrm{S} / 37 / 19$, titled "Strategie kariery kobiet na stanowiskach kierowniczych w branży IT i branży HR”.

\section{References}

Balcita A.M., Carver D., Soffa M.L., Shortchanging the future of information technology: the untapped resource, "SIGCSE Bulletin" 2002, vol. 34, no. 2, pp. 32-35.

Bardin L., Content analysis, Edições, São Paulo 2011.

Bhattacharjee S.D., Takruri-Rizk H., Gender segregation and ICT: an Indo-British comparison, "International Journal of E-Politics" 2011, vol. 2, no. 1, pp. 45-67.

Brenner O., Tomkiewicz J., Schein V.E., The relationship between sex role stereotypes and requisite management characteristics revisited, "Academy of Management Journal" 1989, vol. 32, no. 3, pp. 662-669.

Dodge K.A., Gilroy F.D., Fenzel L.M., Requisite management characteristics revisited: two decades later', [in:] N. Struthers (ed.), Gender in the Workplace, "Journal of Social Behavior and Personality" 1995, vol. 10, special issue, pp. 253-264.

Dube L., Pare G., Rigor in information systems positivist case research: current practices, trends and recommendations, "MIS Quarterly" 2003, vol. 27, no. 4, pp. 597-635.

Eagly A.H., Karau S.J., Role congruity theory of prejudice toward female leaders, "Psychological Review" 2002, vol. 109, pp. 573-598.

Erwin C., Social identity in diverse workgroups: an empirical investigation, "Research Journal of International Studies" 2010, vol. 15, pp. 69-76.

Feldman D.C., Ng T.W.H., Careers: mobility, embeddedness, and success, "Journal of Management" 2007 , vol. 33, no. 3, pp. 350-377.

Forum Akademickie, Rusza największy program wspierający kobiety w informatyce "IT for SHE", https://forumakademickie.pl/news/rusza-najwiekszy-program-wspierajacy-kobiety-w-in formatyce-it-for-she/ (accessed: 10.12.2019). 
Fox M.L., Dot everyone - power, the internet and you, Richard Dimbleby Lecture, 2015, March 30, www.bbc.co.uk/mediacentre/speeches/2015/martha-lane-fox-dot-everyone (accessed: 10.11.2019).

Gherardi S., Poggio B., Creating and recreating gender order in organizations, "Gender \& Society" 2001, vol. 4, no. 2, pp. 139-158.

Glass J.L., Sassler S., Levitte Y., Michelmore K.M., What's so special about STEM? A comparison of women's retention in STEM and professional occupations, "Social Forces" 2013, vol. 92, no. 2, pp. 723-756.

Griffiths M., Moore K., Richardson H., Celebrating heterogeneity? A survey of female ICT professionals in England, "Information, Communication and Society" 2007, vol. 10, no. 3, pp. 338-357.

Gupta N., Rethinking the relationship between gender and technology: a study of the Indian example, “Work Employment and Society”, December 2015, vol. 29, no. 4, pp. 661-672.

Hamilton D.L., Sherman J.W., Stereotypes, [in:] R.S. Wye Jr., T.K. Srull (eds), Handbook of social cognition, vol. 2, applications, Erlbaum, Hillsdale 1994, pp. 1-68.

Hewlett S., Baby Hunger: The New Battle for Motherhood, Atlantic Books, London 2002.

Hilton J.L., Hippel W. von, Stereotypes, “Annual Review of Psychology” 1996, vol. 47, pp. 237-271.

Jayaweera S., Sanmugam T., Wanasundara L., Information and communication technologies and gender in Sri Lanka, Institute of Social Studies Trust, New Delhi 2006.

Karakowsky L., McBey K., Chuang Y., Perception of team performance: the impact of group composition and task based cues, "Journal of Managerial Psychology" 2004, vol. 19, no. 5, pp. 506-525.

Kovacs D.M.W., Ryan M., Haslam A., The glass-cliff: women's career paths in the UK private IT sector, "Equal Opportunities International" 2006, vol. 25, no. 8, pp. 674-687.

Kyriakidou O., Fitting into technical organizations? Exploring the role of gender in construction and engineering management in Greece, "Construction Management and Economics" 2012, vol. 30 , no. 10 , pp. $845-856$.

Lemons M.A., Parzinger M., Gender schemas: a cognitive explanation of discrimination of women in technology, "The Journal of Business and Psychology" 2007, vol. 22, no. 1, pp. 91-98.

Liu J., Wilson D., The unchanging perception of women as managers, "Women in Management Review" 2001, vol. 16, no. 4, pp. 163-173.

Lyness K., Heilman M., When fit is fundamental: performance evaluations and promotions of upper-level female and male managers, "Journal of Applied Psychology" 2006, vol. 91, no. 4, pp. 777-785.

Marshall J., Women Managers: Travellers in a Male World, John Wiley \& Sons, Chichester 1984.

Miller L., Wood T.A., Halligan J., Keller L., Pike C.H., Kornbrot D., Lotz J. de, Saying welcome is not enough: women, information system and equity in work, "Career Development" 2000, vol. 5, no. 7, pp. 379-389.

Mitchell T., Holtom B.C., Lee T.W., Sablynski C.J., Erez M., Why people stay: using job embeddedness to predict voluntary turnover, "Academy of Management Journal” 2001, vol. 44, no. 6 , pp. 1102-1121.

NASSCOM Report. Gender inclusivity and diversity in the Indian IT-BPO industry, NASSCOM, New Delhi 2008.

O'Neill R.M., Gender and race in mentoring relationships: a review of the literature, [in:] D. Clutterbuck, B.R. Ragins (eds), Mentoring and Diversity: An International Perspective, ButterworthHeinemann, Oxford 2002, pp. 1-22.

Perspektywy rozwoju polskiej branży ICT do roku 2025, https://www.parp.gov.pl/component/pub lications/publication/perspektywy-rozwoju-branzy-ict-do-roku-2025 (accessed: 2.01.2020).

Porter E., UBS ordered to pay \$29 million in sex bias lawsuit, "The New York Times" 2005, 7 April. 
Rigg C., Sparrow J., Gender, diversity and working styles, "Women in Management Review" 1994, vol. 9, no. 1, pp. 9-16.

Schein V.E., A global look at psychological barriers to women's progress in management, "Journal of Social Issues" 2001, vol. 57, no. 4, pp. 675-688.

Schein V.E., Relationship between sex role stereotypes and requisite management characteristics among female managers, "Journal of Applied Psychology" 1975, vol. 60, no. 3, pp. 340-344.

Schein V.E., The relationship between sex roles stereotypes and requisite management characteristics, "Journal of Applied Psychology" 1973, vol. 57, no. 2, pp. 95-100.

Schein V.E., Women in management: reflections and projections, presented at the 26th International Congress of Applied Psychology, Athens, 17 July 2006.

Still L.V., Glass ceilings and stick floors: barriers to the careers of women in the Australian finance industry, Human Rights and Equal Opportunity Commission, Commonwealth of Australia, Canberra 1997.

Sudhakar G.P., Farooq A., S. Patnaik, Soft factors affecting the performance of software development teams, "Team Performance Management" 2011, vol. 17, no. 3, pp. 187-205.

Syed M., Murray P., A cultural feminist approach towards managing diversity in top management teams, "Equal Opportunities International" 2008, vol. 27, no. 5, pp. 413-432.

Valenduc G., Vendramin P., Work organisation and skills in ICT professions: the gender dimension, [in:] Proceedings of ICT, the Knowledge Society and Changes in Work, Den Haag 2005.

Wallace J.E., Gender and supportive co-worker relations in the medical profession, "Gender, Work \& Organization" 2014, vol. 21, no. 1, pp. 1-17.

Williams J.E., Best D.L., Measuring sex stereotypes: A multination study, Sage, Newbury Park 1990.

Wood G.J., Newton J.N., Childlessness - a choice among women in Management?, "Gender, Work and Organization" 2006, vol. 3, no. 4, pp. 338-358.

Wood G.J., Newton J.N., Facing the wall' - 'equal'opportunity for women in management? "Equal Opportunities International" 2006, vol. 25, no. 1, pp. 8-24.

Zhang M., Fried D.D., Griffeth R.W., A review of job embeddedness: conceptual, measurement issues, and directions for future research, "Human Resource Management Review" 2012, vol. 22, no. 3, pp. 220-231.

Zhao E., Liu L., Comments on development of job embeddedness about study on turnover and exploration into application in enterprises, "Asian Social Science" 2010, vol. 7, no. 6, pp. 63-70.

Abstract

The attraction of skilled and competent women to traditionally male dominated occupations, and their retention, have now become a great concern for today's organizations. Not enough is known about the challenges faced by women professionals who possess the credentials, skills and knowledge that would allow them to be considered, alongside their male counterparts, for top-rank positions. Therefore, the purpose of the following paper is to identify and delineate the barriers for women in IT managerial positions. The research is based on 10 semi-structured interviews with women who occupy IT managerial positions. Participants were self-recruited following a call for participation in research posted to graduate students at Warsaw School of Economics. Findings show that the IT industry is predominantly masculine, and women are expected to perform roles similar to their male counterparts. The study identified different strategies used by women to compromise their gender identities and fit within their work environments.

Keywords: women in IT managerial positions, gender role stereotypes, competent women 